Arab Univ. J. Agric. Sci., Ain Shams Univ., Cairo, 14(1), 365-377, 2006

\title{
EVALUATION OF SOME MALE TYPES AS POLLINATORS FOR BARHI DATE PALM cv. GROWN IN EGYPT
}

\section{[24]}

\author{
Al-Hamoudi ${ }^{1}$, A.H.; A.M. El-Hammady ${ }^{2}$; I.M. Desouky ${ }^{2}$; \\ and A. Abdel-Hamid ${ }^{2}$
}

\begin{abstract}
Four different date palm male types were chosen to evaluate which male could be recommended to use as a pollinator for Barhi date palm cv. grown in Egypt. Three male types namely Ghanamy, Fard and Boyr were grown in the Fruit Trees Experimental Station at Dibba, Fojaira, UAE, and the fourth male was an individual Sewy satellite seedling grown in Egypt. Number of spathe/palm; spathe weight, length, \& width ; pollen grains weight / spathe ; average of strand length as well as pollen grains germination \% were determined for each male date palm tree from each male type . Moreover, pollen grains from each male type were used as a pollinator to evaluate their effect on fruit set and fruit quality of Barhi date palm cv. This study was carried out during both 2004\&2005 seasons. Data showed that both Ghanamy and Fard male type were superior in their morphological characters as compared with Boyr or Sewy satellite seedling male type. Boyr male type showed the lowest values of morphological characters. On the other hand, there were no great differences in pollen grains germination percentage. Moreover, the results clearly indicated that Ghanamy pollen recorded the highest significant fruit set percentage and bunch weight $(\mathrm{Kg})$ in both seasons of study. While, Fard pollen produced the highest fruit weight $(\mathrm{g})$, length, diameter, flesh weight\& thickness and flesh \%. Boyr and Sewy pollen showed the highest ratio of fruit length / diameter in both seasons. Data also revealed that dates that were picked from bunches pollinated with Fard pollen had the highest total soluble salts (T.S.S) value and the lowest tannins content.
\end{abstract}

Keywords: Date palm, Male types, Fruit set, Fruit quality, Barhi cv.

\section{INTRODUCTION}

Date palm is one of the most important fruit trees in Egypt and Arab countries. It is dioecious with female and male flowers occurring on separate palms.

Artificial pollination is necessary for successful fruiting. In some date cultivars, better fruit set resulted from pollen of some males than others, due to compatibility of male female varieties. Many in-

1- Min. of Agric. \& Fisheries, UAE

2- Dept. of Hort. , Fac. of Agric., Ain Shams Univ., Shoubra El-Kheima, Cairo Egypt

(Received November 27, 2005)

(Accepted December 7, 2005) 
vestigators proved that pollen grains from different male date trees not only influence the size and shape of seed (xinia) but also has a direct effect on fruit set, yield and fruit physical and chemical characteristics (metaxinia) Nixon, (1935), Nixon, (1936), Mathew et al (1975), Ream, (1976), (El-Hammady et al (1977), Hussein et al (1979), and ElGhayaty (1982). Also, Shaheen et al (1989a\&b) El-Salhy et al (1997) reported that pollen source was found to affect fruit and seed characteristics and it exhibited metaxinic effect depending on the female cultivar used.

Recently, Abdel-Hamid (2000) accentuated the metaxinic effect of Maghal, Zaghloul and Hayany males on Zaghloul date fruits including high fruit set, less fruit abscission, earlier fruit maturity, high bunch and fruit weight compared to other male parents. Flesh weight $\%$, fruit length \& diameter, T.S.S and tannins content found to be improved with pollens from Maghal, Zaghloul and Hayany than other males.

\section{MATERIAL AND METHODS}

This study was conducted during two successive seasons of 2004 and 2005 on Barhi date palm cv. of about seven-yearsold planted at $8 \times 8 \mathrm{~m}^{2}$ apart in a clay soil at a private orchard located in Berma village, Tanta, Gharbia Governorate, Egypt. The selected palms were produced throughout tissue culture technique and they were uniform in size and vigour. All palms were healthy and subjected to the same cultural practices in both seasons. The leaf / bunch ratio was maintained at $8: 1$. Eight female spathes of nearly equal size were retained on each selected palm in both seasons.
The mature male spathes were cut off from one male palm tree of the three male types namely Ghanamy, Fard and Boyr grown in Fruit Trees Experimental Station at Dibba, Fojaira, UAE, and the fourth male was Sewy (an individual Sewy satellite seedling as suggested by Mason , 1927) grown in Egypt .

The strands of each spathe were detached and spread in a thin layer on paper sheets 4-5 days till drying then the pollen grains were separated from the flowers. Two female spathes on each palm tree were pollinated directly after the spathe cracking with one of the four male types. The pollens were backed in aluminium bags and stored in ice box. Hand pollination was done by dusting the dry pollen grains on a piece of cotton about the size of walnut fruit, then they were placed within the strands of the female spathe. Each spathe was pollinated with an equal amount of pollen grain (about $1 \mathrm{gm}$ ) then the distal end of the spathe was tied.

After pollination, the female spathes were covered with perforated paper bags $(60 \times 30 \mathrm{~cm})$ to prevent any contamination with foreign pollen grains (Plate 1). The bags were carefully tied around the end of the spathe and then shaken gently to insure the spread of pollen grains among the female flowers.

After two weeks, the bags were removed. The number of flowers and fruits setting on twenty five strands per spathe were recorded after eight weeks of pollination to determine fruit set percentage.

The bunches of all treatments were harvested at full color (Khalal stage) in 14 and 21 October during 2004 and 2005 seasons, respectively, and the average bunch weight $(\mathrm{kg})$ was calculated. Four 
Plate 1. Female spathes of Barhi date palm cv. covered with perforated paper bags

samples from each treatment were picked at random. Each sample contained 25 fruits for the determination of fruit length titratable acidity $\%$ and tannins $\%$ were determined in the fruit flesh according to the A.O.A.C. methods (1980).

Each treatment was replicated four times and each replicate was represented by one palm tree with two spathe on each palm (4 treatments $x 4$ palm x 2 female spathes for each male type).

The experiment was arranged in a completely randomized blocks design. Duncan's multiple range test was employed to compare between means according to Snedecor and Chochran (1972).

The morphological characters of the four male types were measured i.e. number of spathe per male palm, spathe $(\mathrm{cm})$, fruit diameter $(\mathrm{cm})$, fruit weight (g), flesh weight, thickness and flesh \%. Values of total soluble solids (T.S.S), weight $(\mathrm{Kg})$, spathe length $(\mathrm{cm})$, spathe width $(\mathrm{cm})$ strands length $(\mathrm{cm})$ and spathe pollen grains weight $(\mathrm{g})$. However, pollen germination \% was measured according to the method described by Boughedri and Baunaga (1987).

\section{RESULTS AND DISCUSSION}

Data in Tables (1 and 2) showed the morphological characters of the four male type i.e. number of spathe per male palm, spathe weight $(\mathrm{Kg})$, spathe length $(\mathrm{cm})$, spathe width $(\mathrm{cm})$ strands length $(\mathrm{cm})$ and spathe pollens grains weight $(\mathrm{g})$ and pollen germination \%, during.2004 and 2005 seasons. Data showed that both 
Table 1. Morphological characters of different male types used for Barhi date palm cv. pollination during 2004 and 2005 seasons

\begin{tabular}{|lcccccc|}
\hline Male type & $\begin{array}{c}\text { Number } \\
\text { of spathes } \\
\text { /palm }\end{array}$ & $\begin{array}{c}\text { Spathe } \\
\text { weight } \\
(\mathrm{Kg})\end{array}$ & $\begin{array}{c}\text { Spathe } \\
\text { length } \\
(\mathrm{cm})\end{array}$ & $\begin{array}{c}\text { Spathe } \\
\text { width } \\
(\mathrm{cm})\end{array}$ & $\begin{array}{c}\text { Stand } \\
\text { length } \\
(\mathrm{cm})\end{array}$ & $\begin{array}{c}\text { Pollen grains } \\
\text { weight }(\mathrm{g}) \\
\text { per spathe }\end{array}$ \\
\hline Sewy* & 15 & 1.74 & 71 & 11.4 & 22 & 12.4 \\
Ghanamy & 19 & 1.80 & 73 & 19.1 & 24 & 13.0 \\
Fard & 21 & 1.95 & 75 & 16.5 & 26 & 12.5 \\
Boyr & 17 & 0.98 & 60 & 13.2 & 18 & 9.5 \\
\hline & & & $\mathbf{2 0 0 5}$ season & \\
\hline Sewy* & 16 & 1.60 & 72 & 11.3 & 20 & 11.9 \\
Ghanamy & 21 & 1.93 & 75 & 18.2 & 23 & 13.7 \\
Fard & 20 & 1.90 & 78 & 17.5 & 28 & 13.2 \\
Boyr & 17 & 1.25 & 65 & 15.0 & 20 & 12.5 \\
\hline
\end{tabular}

* Sewy satellite seedling

Table 2. Pollen grains germination percentage of different male types used in Barhi date palm cv. pollination during.2004 and 2005 seasons

\begin{tabular}{|lcc|}
\hline \multirow{2}{*}{ Male type } & \multicolumn{2}{c|}{ Pollen grains germination \% } \\
\cline { 2 - 3 } & 2004 & 2005 \\
\hline Sawy* & 90.7 & 88.2 \\
Ghanami & 89.5 & 90.0 \\
Fard & 91.8 & 92.5 \\
Boyr & 86.1 & 87.5 \\
\hline
\end{tabular}

* Sewy satellite seedling 
Ghanamy and Fard male type were superior in their morphological characters in both 2004 and 2005 seasons. Whereas, Boyr male type showed the lowest values of morphological characters. On the other hand, there were no great differences in pollen grains germination percentage in both seasons among the four studied male types.

Data in Tables (3, 4 and 5) showed the effect of different male types namely Sewy, Ghanamy, Fard, and Boyr on fruit set percentage, bunch weight $(\mathrm{Kg})$ and fruit quality of Barhi date cv. during 2004 and 2005 seasons.

\section{Fruit set percentage}

The highest significant fruit set percentages (34.15 and 33.03) were recorded by Ghanamy pollen in 2004 and 2005 seasons respectively. Meanwhile, the lowest values were obtained by Fard and Sewy pollen in both seasons of study without significant difference between them (Plate, 2).

\section{Bunch weight $(\mathrm{Kg})$}

Concerning bunch weight $(\mathrm{Kg})$, data revealed that Ghanamy pollen gave the highest significant bunch weight $(\mathrm{Kg})$ in both seasons. On the other hand, the lowest bunch weight was noticed with Sewy and Fard pollen during 2004 and 2005 seasons.

Data indicated that bunch weight $(\mathrm{Kg})$ significantly increased as fruit set percentage increased during both seasons of study. Similar observations were also found by Shaheen et al (1989a) and ElSalhy et al (1997) who reported that there was a positive correlation between fruit set percentage and bunch weight obtained at harvest.
Data also cleared that Ghanamy pollen achieved the highest significant fruit set percentage and bunch weight $(\mathrm{Kg})$ in both seasons of study. These findings are in line with those of El-Hammady et al (1977), Nixon and Carpenter (1978) and El-Ghayaty (1982). They also recorded variable degree of compatibility in some date varieties and variable fruit set percentages by different pollinators.

\section{Fruit physical properties}

\section{Fruit weight (g)}

As for fruit weight (g), results indicated that Fard and Ghanamy pollen significantly increased the fruit weight (g) during the first season compared to Sewy and Boyr pollens. In the second season, Fard pollen induced the highest value. The lowest fruit weight (g) was observed with Sewy and Boyr pollens during 2004 season and with Sewy and Ghanamy pollen during 2005 season.

\section{Fruit length (cm)}

Data revealed that Fard pollen produced the tallest fruit during 2004 and 2005 seasons (Table, 3). While, Sewy and Ghanamy pollens recorded the lowest values. Insignificant differences among the different male types were noticed in the second season.

\section{Fruit diameter (cm)}

Regarding the fruit diameter, data showed that the highest significant fruit diameter $(\mathrm{cm})$ was obtained by Fard and Ghanamy pollens during the first season without significant difference between them. In the second season, Fard pollen produced the highest value. 
Table 3. Effect of different male types on fruit set, bunch weight $(\mathrm{kg})$ and fruit weight $(\mathrm{g})$, length $(\mathrm{cm})$ and diameter $(\mathrm{cm})$ of "Barhi" date palm cv. during 2004 and 2005 seasons

\begin{tabular}{|lccccc|}
\hline Male type & $\begin{array}{c}\text { Fruit } \\
\text { set } \%\end{array}$ & $\begin{array}{c}\text { Bunch } \\
\text { weight } \\
(\mathrm{kg})\end{array}$ & $\begin{array}{c}\text { Fruit weight } \\
(\mathrm{g})\end{array}$ & $\begin{array}{c}\text { Fruit length } \\
(\mathrm{cm})\end{array}$ & $\begin{array}{c}\text { Fruit } \\
\text { diameter } \\
(\mathrm{cm})\end{array}$ \\
\hline \multicolumn{5}{c}{$\mathbf{2 0 0 4}$ season } \\
\hline Sewy* & $14.92 \mathrm{C}$ & $6.11 \mathrm{~B}$ & $13.70 \mathrm{C}$ & $2.31 \mathrm{C}$ & $1.49 \mathrm{BC}$ \\
Ghanamy & $34.15 \mathrm{~A}$ & $11.87 \mathrm{~A}$ & $15.19 \mathrm{AB}$ & $2.52 \mathrm{~B}$ & $1.61 \mathrm{AB}$ \\
Boyr & $20.13 \mathrm{~B}$ & $7.07 \mathrm{~B}$ & $14.50 \mathrm{BC}$ & $2.37 \mathrm{C}$ & $1.37 \mathrm{C}$ \\
Fard & $13.13 \mathrm{C}$ & $6.03 \mathrm{~B}$ & $16.08 \mathrm{~A}$ & $2.64 \mathrm{~A}$ & $1.75 \mathrm{~A}$ \\
\hline \multicolumn{5}{c}{$\mathbf{2 0 0 5}$ season } \\
\hline Sewy* & $16.29 \mathrm{C}$ & $6.29 \mathrm{C}$ & $14.31 \mathrm{C}$ & $2.49 \mathrm{~A}$ & $1.39 \mathrm{C}$ \\
Ghanamy & $33.03 \mathrm{~A}$ & $10.51 \mathrm{~A}$ & $13.98 \mathrm{C}$ & $2.47 \mathrm{~A}$ & $1.54 \mathrm{~B}$ \\
Boyr & $21.59 \mathrm{~B}$ & $8.10 \mathrm{~B}$ & $15.41 \mathrm{~B}$ & $2.49 \mathrm{~A}$ & $1.51 \mathrm{BC}$ \\
Fard & $15.72 \mathrm{C}$ & $7.10 \mathrm{BC}$ & $17.00 \mathrm{~A}$ & $2.53 \mathrm{~A}$ & $1.86 \mathrm{~A}$ \\
\hline
\end{tabular}

* Sewy satellite seedling

Means having the same letter (s) within each column are insignificantly different at 5\% level.

Table 4. Effect of different male types on fruit L/D ratio, flesh weight (g), flesh thickness (cm), and flesh \% of "Barhi" date palm cv. during 2004 and 2005 seasons

\begin{tabular}{|lcccc|}
\hline \multicolumn{1}{|c}{ Male type } & $\begin{array}{c}\text { L/ D } \\
\text { Ratio }\end{array}$ & $\begin{array}{c}\text { Flesh weight } \\
(\mathrm{g})\end{array}$ & $\begin{array}{c}\text { Flesh thickness } \\
(\mathrm{cm})\end{array}$ & Flesh \% \\
\hline \multicolumn{5}{c}{$\mathbf{2 0 0 4}$ season } \\
\hline Sewy* & $1.55 \mathrm{~B}$ & $12.11 \mathrm{c}$ & $0.58 \mathrm{~B}$ & $88.39 \mathrm{C}$ \\
Ghanamy & $1.57 \mathrm{~B}$ & $13.87 \mathrm{AB}$ & $0.59 \mathrm{~B}$ & $91.31 \mathrm{~B}$ \\
Boyr & $1.73 \mathrm{~A}$ & $13.10 \mathrm{BC}$ & $0.58 \mathrm{~B}$ & $90.34 \mathrm{~B}$ \\
Fard & $1.51 \mathrm{~B}$ & $14.90 \mathrm{~A}$ & $0.63 \mathrm{~A}$ & $92.54 \mathrm{~A}$ \\
\hline \multicolumn{5}{c}{$\mathbf{2 0 0 5}$ season } \\
\hline Sewy* & $1.79 \mathrm{~A}$ & $13.95 \mathrm{~B}$ & $0.56 \mathrm{~B}$ & $90.28 \mathrm{~B}$ \\
Ghanamy & $1.60 \mathrm{~B}$ & $14.56 \mathrm{~B}$ & $0.58 \mathrm{~B}$ & $90.03 \mathrm{~B}$ \\
Boyr & $1.65 \mathrm{~B}$ & $17.07 \mathrm{~A}$ & $0.57 \mathrm{~B}$ & $91.10 \mathrm{AB}$ \\
Fard & $1.36 \mathrm{C}$ & $16.57 \mathrm{~A}$ & $0.61 \mathrm{~A}$ & $92.18 \mathrm{~A}$ \\
\hline
\end{tabular}

* Sewy satellite seedling

Means having the same letter (s) within each column are insignificantly different at $5 \%$ level. 
Table 5. Effect of different male types on fruit T .S.S. \%, titratable acidity \% and tannins \% of "Barhi" date palm cv. during 2004 and 2005 seasons.

\begin{tabular}{|lccc|}
\hline \multicolumn{1}{|c}{ Male type } & T .S.S. \% & $\begin{array}{c}\text { Titratable acidity } \\
\%\end{array}$ & Tannins \% \\
\hline \multicolumn{3}{c}{$\mathbf{2 0 0 4}$ season } \\
\hline Sewy* & $24.10 \mathrm{~B}$ & $0.081 \mathrm{~A}$ & $0.23 \mathrm{~A}$ \\
Ghanamy & $24.00 \mathrm{~B}$ & $0.082 \mathrm{~A}$ & $0.21 \mathrm{~A}$ \\
Boyr & $26.90 \mathrm{AB}$ & $0.085 \mathrm{~A}$ & $0.22 \mathrm{~A}$ \\
Fard & $29.40 \mathrm{~A}$ & $0.083 \mathrm{~A}$ & $0.22 \mathrm{~A}$ \\
\hline & & $\mathbf{2 0 0 5}$ season & \\
\hline Sewy* & $28.20 \mathrm{~B}$ & $0.086 \mathrm{~A}$ & $0.24 \mathrm{~A}$ \\
Ghanamy & $30.40 \mathrm{~B}$ & $0.074 \mathrm{~A}$ & $0.22 \mathrm{~B}$ \\
Boyr & $35.00 \mathrm{~A}$ & $0.087 \mathrm{~A}$ & $0.21 \mathrm{BC}$ \\
Fard & $36.10 \mathrm{~A}$ & $0.083 \mathrm{~A}$ & $0.19 \mathrm{C}$ \\
\hline
\end{tabular}

* Sewy satellite seedling.

Means having the same letter (s) in each a column are insignificantly different at $5 \%$ level.

On the other hand, the lowest values were observed with Boyr and Sewy pollens without significant difference between them during both seasons of study.

\section{Fruit shape index (L/D ratio)}

Data clearly indicated that the highest L/D ratio (1.37) was achieved by Boyr and Sewy pollen compared with the other male types during 2004 and 2005 seasons.

On the other hand, Fard pollen showed the lowest values in both seasons and the difference was significant only in the second season. Ghanamy pollen gave generally an intermediate value.
It was obvious that Boyr and Sewy pollens produced elongated fruits in the first and second seasons, respectively. While, Ghanamy and Fard pollens produced nearly round fruits during the second season.

\section{Flesh weight (g)}

As for the effect of male types on flesh weight $(\mathrm{g})$, it is obvious that Fard pollen exhibited the highest flesh weight (g) followed by Ghanamy pollen without significant difference between them in the first season. Moreover, in the second season, the greatest values were produced by Boyr and Fard pollens without significant 
difference between them. Meanwhile, Sewy pollen gave the lowest flesh weight $(\mathrm{g})$ in both seasons of study.

\section{Flesh thickness (cm)}

Concerning flesh thickness, data indicated that the highest significant flesh thickness was achieved by Fard pollen compared with the other pollen types in both seasons. While Sewy pollen gave the lowest values in both seasons.

\section{Flesh \%}

The obtained results indicated that the flesh weight $\%$ differed significantly according to pollen type. Fard pollen significantly increased the flesh weight percentage of Barhi dates than other male types in 2004 season. Whereas, both Fard and Boyr pollens produced the highest significant values in 2005 season without significant difference between them.

On the other hand, the lowest flesh \% was recorded by Sewy and Ghanamy pollens in the first and second seasons, respectively.

It could be concluded from the obtained results that Fard pollen produced the highest fruit weight, length and diameter and flesh weight, thickness and flesh\%. Meanwhile, Boyr and Sewy pollens gave the highest L/D ratio in the first and second seasons, respectively. Boyr and Sewy pollens produced elongated fruits. While, Ghanamy and Fard pollens produced ovate fruits (Plate, 2 ).

These results are in harmony with those found by Shroeder and Nixon (1958) El-Hammady et al (1977) and Abd El-Hamid (2000) who reported that pollen affects the fruit shape, weight and flesh weight.

\section{Fruit chemical properties}

Total soluble solids percentage (T.S.S. \%)

Results in Table (5) showed that T.S.S.\% varied considerably with pollen grains type. Barhi fruits were significantly higher in T.S.S. when pollinated with Fard pollen followed in a decreasing order by Boyr pollen without significant difference between them. Whereas, the lowest T.S.S.\% were recorded by Sewy and Ghanamy pollen in both seasons of study.

\section{Titratable acidity \%}

Regarding the effect of pollen types on titratable acidity $\%$, data revealed that there were no significant differences between the different male types on titratable acidity $\%$ of Barhi dates in both seasons of study.

\section{Tannins \%}

Data also indicated that there were insignificant differences between the four male types in tannins \% during 2004 season.

Fard pollen gave the lowest tannins value. While Sewy pollen recorded the highest significant tannins content in 2005 season.

It could be concluded that T.S.S. \% varied considerably with pollen type where the highest T.S.S. value was obtained by Fard pollen. Meanwhile, there were no significant differences between 
Plate 2. Fruit setting of Barhi date palm cv. as affected by different male types:

a- Sewy

b- Ghanamy

c- Fard

d- Boyr

Arab Univ. J. Agric. Sci., 14(1), 2006 
Plate 3. Effect of male types on fruit stape and fruit quality of Barhi date palm cv. a- Sewy satellite seedling

b- Ghanamy

c- Boyr

d- Fard

the different male types on titratable acidity $\%$. The lowest tannins content was recorded by Fard pollen. This results are in agreement with those found by Shaheen et al (1989b); Abd El-Hamid (2000) who reported that fruit chemical properties were found to be affected with pollen type.

Finally, the results clearly indicated that Ghanamy and Fard male types were superior in their morphological characters .Moreover, Ghanamy male type found to be the most suitable pollinator for Barhi date palm cv. which significantly improved fruit set percentage and increased bunch weight $(\mathrm{Kg})$ in both seasons of study. While, Fard pollen produced the highest fruit weight (g), length, diameter, flesh weight\& thickness and flesh \%.

\section{REFERENCES}

Abdel-Hamid, N. (2000). Effect of time, role and patterns of thinning, leaf/bunch ratio and male type on "Zaghloul" date yield and quality. Arab Univ. J. Agric. Sci. Ain Shams Univ., Cairo 8(1): 305318.

A.O.A.C. (1980). Association of Official Analytical Chemists. Methods of Analysis. $13^{\text {th }}$ Ed., Washington D.C.. 
Boughedri, L. and N. Baunaga (1987). In vitro germination of date pollen and its relation of fruit set. Date Palm Journal, 5(2): 120-127.

El-Ghayaty, S.H. (1982). Effect of different pollinators on fruit setting and some fruit properties of Siwi and Amhat date varieties. Proc. $1^{\text {st }}$ Symposium on Date Palm. College of Agricultural Sciences and Food, King Faisal University, Al-Hassa, Saudi Arabia. pp. 72-82.

El-Hammady, M.M.; A.S. Khalifa and A.M. El-Hammady (1977). The effect of date pollen on some physical and chemical characters of "Hayani" variety. Res. Bull. No 733, Fac. Agric., Ain Shams Univ., Cairo, Egypt.

El-Salhy, A.; A. Abdalla and R. Mostafa (1997). Evaluation of some date palm male seedlings in pollination of Zaghloul and Samany date palms under Assiut conditions. Assiut Journal of Agricultural Scince. 28(2): 79-89.

Hussein, F.; S. Moustafa and I. Mahmoud (1979). The direct effect of pollen (metaxenia) on fruit characteristics of dates grown in Saudi Arabia. Biological Society Proceeding, Third Conference, Al-Hassa, Saudi Arabia, pp. 6978.

Mathew, C.; A.H. Al-Rawi; A. AlZubahidi; M. Shukur; S. Al-Obaidi and Z. Al-Doori (1975). The effect of different types of pollen grains on the khastawi date fruit. Pollination of / individual trees with different pollens. International Palm Date $3^{\text {th }}$ Conf. pp. 1-17. Baghdad.
Mason, S.C. (1927) Date culture in Egypt and Sudan. USDA Bul. No. 1457, $27 p p$.

Nixon, R.W. (1935). Metaxenia in date. Proc. Amer. Soc. Hort. Sci. 32: 221-226. Nixon, R.W. (1936). Further experiments in Fruit thinning of date palm. Date Grower's Inst. Rep. 13: 6-8.

Nixon, R.W. and J.B. Carpenter (1978). Growing dates in the United States. U.S. Dept. of Agric. Bull. No. 207.

Ream, C.L. (1976). Metaxinia effect of pollen form inbred male palms on ripening period and size of date fruit. Date Grower's Inst. Rep. 53: 21-226.

Shaheen, M.A.; T.A. Nasr and M.A. Bacha (1989a). Effect of male type on fruit setting, yield and fruit physical properties in some date palm cultivars. Annals Agric. Sci., Fac. Agric., Ain Shams Univ. Cairo, Egypt. 34(1): 283299.

Shaheen, M.A.; M.A. Bacha and T.A. Nasr (1989b) Effect of male type on fruit chemical properties in some date palm cultivars. Annals Agric. Sci., Fac. Agric., Ain Shams Univ. Cairo, Egypt. 34(1): 265-281.

Snedecor, G.W. and W.G. Chochran (1972). Statistical Methods, $6^{\text {th }}$ Ed., 593. pp. The Iowa State University Press, Ames, Iowa. USA.

Shroeder, C.A. and R.W. Nixon (1958). morphological effects of specifc pollens and fruit thining on fruits of Deglet noor dates. Date Growers Inst., Rep. 35: 3517. 


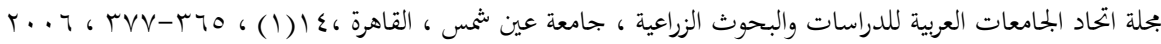

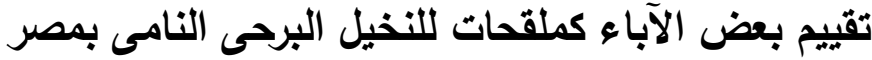

[Y $\{$ ]

علي حسن الحمودي' - عبد العظيم محمد الحمادي' - إبراهيم محمد دسوقي ' -

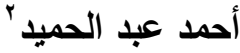

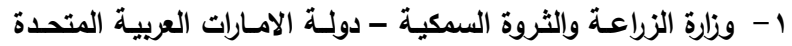

r- قسم البساتين - كلية الزراعة - جامعة عين شمس - شبرا الخيمة - القاهرة - مصر

لاراسة تأثنير لقاح الآباء المختلفة على النسبة

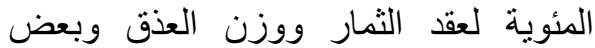

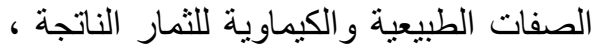
وقد تم تنفيذ هذه الدراسة خلال موسمى واليمى

$$
\text { r... }
$$

وقد أوضحت نتائج هذه الدراسـة أن كل

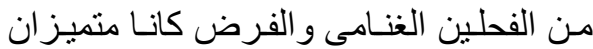

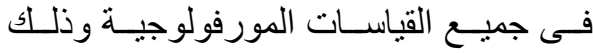

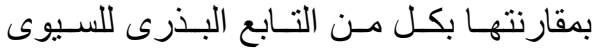

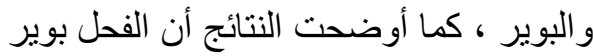

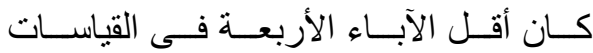

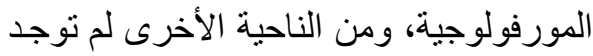

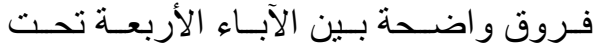

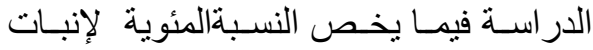
حبوب اللقاح. وقد أكدت النتائج أن حبوب لقاح الغنامى الفي

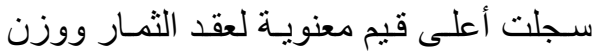
العذق (بـالكجم) خـلال موسمى الديم الدر اسـة. بينما

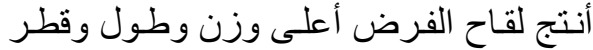
للثمرة وكذللك أعلى وزن وسمك ونسبة لحم وطم
أجريت هذه الدراسة بهدف تقييم أربعة أباء مختلفة من نخيل التمر من حيث إمكانية


تحت ظروف جمهورية مصر العربية ـوقدان تم اختيار ثثلاث آباء نامية بمحطة التجارب

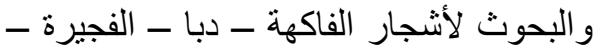
دولة الإمارات العربية المتحدة وهذه الآباء

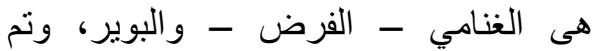
إختيار فحل نخيل تمر كثجرة فردية ونظر الفي الفيرو

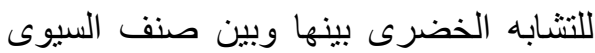
فإنه يمكن أن يطلق عليها التابع البذرى للسيوى Sewy satellite seedling كما إقترح

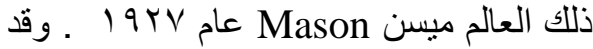
تم دراسة الصفات الخضرية لهذه الآباء مثل

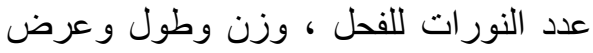
الأغريض ، وزن حبوب اللقاح لكل إغريض وطول

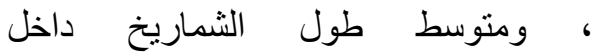
الإغريض.كما نم إستخدام حبوب اللقاح من الإن كل من الآباء السابق الإشارة إليها فى تلقيح

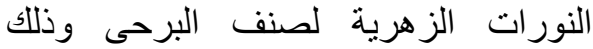




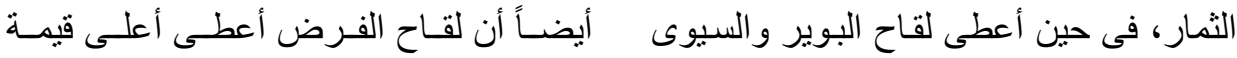

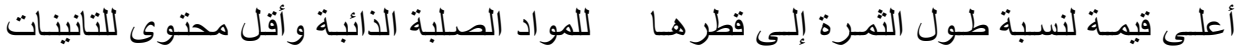

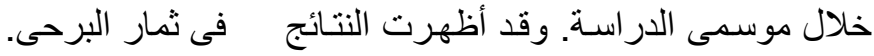

تحكيم: أ.د محمد أبو رواش على بدر

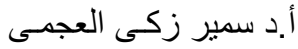

